\title{
Analisis Pengambilan Keputusan Penentuan Prioritas Utama Dalam Peningkatan Kualitas Mata Pelajaran Dengan Menggunakan Metode Perbandingan WASPAS dan MOORA
}

\author{
Chandra Lukital, Chairun Nas ${ }^{2}$, Wanda Ilham ${ }^{3}$ \\ ${ }^{I}$ Sistem Informasi, Universitas Catur Insan Cendekia, Jl. Kesambi No.202, Cirebon, Jawa Barat, Indonesia \\ ${ }^{2}$ Manajemen Informatika, Universitas Catur Insan Cendekia, Jl. Kesambi No.202, Cirebon, Jawa Barat, Indonesia \\ ${ }^{3}$ Teknik Infomatika, Universitas Catur Insan Cendekia, Jl. Kesambi No.202, Cirebon, Jawa Barat, Indonesia
}

\section{INFORMASI ARTIKEL}

\section{Sejarah Artikel:}

Diterima Redaksi: 08 September 2019

Revisi Akhir: 20 Desember 2019

Diterbitkan Online: 05 Januari 2020

\section{KATA KUNCI}

Keputusan, Kualitas,

Mata Pelajaran,

WASPAS,

MOORA

KORESPONDENSI

E-mail: chairun.nas@cic.ac.id

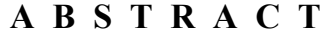

Siswa dituntut untuk dapat memahami setiap materi pelajaran yang diberikan oleh guru. Namun akibat keterbatasan guru dan murid, seringkali materi yang disampaikan tidak dapat dipahami oleh siswa. Tujuan dari penelitian ini adalah untuk membantu pihak sekolah dalam menganalisa materi pelajaran yang perlu diperbaiki dan dikembangkan cara penyampainnya kepada siswa, sehingga siswa dapat memahami pelajaran tersebut. Dalam penelitian ini dilakukan pengolahan data kriteria penilaian dan data alternatif sebanyak 6 jenis mata pelajaran pada siswa kelas XII. Data akan diuji menggunakan metode Multi-Objective Optimization On The Basic Of Ratio Analysist (MOORA) dan metode Weight Aggregated Sum Product Assesment (WASPAS). Hasil pengujian dari kedua metode tersebut, dilakukan pembandingan untuk menentukan keputusan terbaik. Dari hasil penelitian yang dilakukan, ditemukan hasil keputusan pada metode MOORA dengan 3 jenis mata pelajaran yang harus diperbaiki dan pada Metode WASPAS dengan 1 jenis mata pelajaran yang harus diperbaiki. Maka kedua metode ini dapat digunakan dalam menganalisa mata pelajaran yang perlu diperbaiki oleh pihak sekolah.

\section{PENDAHULUAN}

Menghadapi tantangan perkembangan zaman saat ini, pemerintah dengan semangatnya menggalakkan wajib belajar 12 tahun bagi anak-anak indonesia. Hal ini bertujuan untuk meningkatan kualitas manusia yang ada di Indonesia yang mampu bersaing di dunia industri. Untuk mencapai tujuan tersebut, maka pihak sekolah wajib mengadakan proses belajar mengajar yang baik untuk para siswanya. Belajar dan pembelajaran adalah 2 hal yang saling berhubungan erat dan tidak dapat dipisahkan dalam kegiatan edukatif, karena merupakan bentuk edukasi yang menjadikan adanya suatu interaksi antara guru dan siswa [1].

Pada proses pembelajaran, seringkali siswa tidak mampu memahami materi yang disampaikan oleh guru. Ini dibuktikan dengan rendahnya nilai akhir yang diperoleh oleh siswa per semesternya. Dalam proses pembelajaran, sering dijumpai adanya kecenderungan siswa yang enggan bertanya kepada guru meskipun mereka sebenarnya belum mengerti tentang materi yang disampaikan oleh guru [2]. Hal ini perlu adanya perbaikan dari pihak sekolah, apakah perlu pengembangan materi belajar, meningkatkan kualitas guru atau membuat materi pembelajaran semenarik mungkin. Sehingga dengan adanya perbaikan tersebut, dapat meningkatkan nilai akhir dari siswa.

Permasalahan yang dihadapi oleh pihak sekolah saat ini adalah keterbatasan pihak sekolah dalam menentukan mata pelajaran yang perlu ditingkatkan. Disebabkan banyaknya mata pelajaran yang ada disekolah, sehingga membingungkan dalam menentukan prioritas utama dalam memilih mata pelajaran yang perlu diperbaiki kualitasnya. Maka untuk mengatasi masalah tersebut, dibutuhkanlah 
sebuah sistem pendukung keputusan yang mampu melakukan proses pengambilan keputusan dalam menentukan mata pelajaran yang menjadi prioritas utama dalam peningkatan kualitasnya.

Sistem pendukung keputusan adalah salah satu cara mengorganisir informasi yang dimaksudkan untuk digunakan dalam membuat keputusan [3]. Dengan adanya sistem pendukung keputusan, maka dapat membantu para pengambil keputusan menentukan keputusan terbaiknya dalam mengatasi masalah. Dalam sistem pendukung keputusan, pengolahan data dilakukan dengan algoritma dasar atau metode yang sering diperlukan dalam mengambil solusi [4]. Maka dalam sistem pendukung keputusan penentuan mata pelajaran yang menjadi prioritas utama dalam peningkatan kualitas, digunakan metode Multi-Objective Optimization On The Basic Of Ratio Analysist (MOORA) dan metode Weight Aggregated Sum Product Assesment (WASPAS). Kedua metode ini akan dibandingkan hasilnya untuk dipilih hasil terbaik sebagai keputusan.

Metode MOORA atau Multi-Atribute Optimization adalah suatu teknik atau proses mengoptimalkan secara bersamaan dua atau lebih atribut (sasaran) yang saling bertentangan, dimana atribut tersebut memiliki batasannya tertentu [10]. Metode MOORA pernah digunakan oleh Braurers pada tahun 2003 dalam suatu pengambilan keputusan multi kriteria dan pada tahun 2006 diperkenalkan kepada publik oleh Braurers dan Zavadkas. Metode MOORA sendiri merupakan pengembangan dari Multiple Criteria Decission Making (MCDM) dimana didalam metode tersebut terdapat 1 atau lebih kriteria penilaian dalam pengambilan keputusan. Didalam metode MOORA terdiri dari dua fase, yaitu fase pendekatan titik referensi dan pendekatan sistem rasio yang memungkinkan pengukuran kriteria baik dan kurang dalam proses memilih alternatif dari serangkaian alternatif [11]

Metode MOORA memiliki tingkat fleksibilitas dan kemudahan untuk dipahami dalam memisahkan bagian subjektif dari suatu proses evaluasi kedalam kriteria bobot keputusan dengan beberapa atribut pengambilan keputusan [6]. Metode MOORA juga memiliki tingkat selektifitas yang baik, karena dapat menentukan tujuan dan kriteria yang bertentangan, yaitu kriteria yang bernilai menguntungkan (Benefit) atau tidak menguntungkan (Cost) [3].

Dalam prosesnya, metode MOORA memiliki 5 tahapan proses [10], yaitu:

1. Menentukan tujuan, mengidentifikasi atribut dan dan mengevaluasi atribut tersebut.

2. Menentukan nilai matrik keputusan

$\begin{array}{rcc}X 11 & X 12 & X 1 n \\ X i j=X 21 & X 22 & X 2 n \\ X m 1 & X m 2 & X m n\end{array}$

3. Menentukan normalisasi matriks

Disimpulkan oleh Breaures bahwa untuk penyebut atau denominator, pilihan terbaik adalah akar kuadrat dari jumlah kuadrat dan setiap alternatif per atribut. Maka dapat dirumuskan sebagai berikut:

$$
X^{*} i j=\frac{X i j}{\sqrt{\sum_{i=1}^{m} X^{2} i j}}
$$

\section{Menentukan optimalisasi atribut}

Untuk optimasi Multi-Objektif, kinerja yang dinormalisasi ditambahkan dalam kasus maksimasi (untuk atribut yang menguntungkan) dan dikurangi dalam kasus minimasi (untuk atribut non menguntungkan). Namun saat atribut bobot dimasukkan, maka dapat dirumuskan sebagai berikut:

$$
Y i=\sum_{j=1}^{g} \mathrm{~W}_{\mathrm{j}} X_{i j}^{*}-\sum_{j=g+1}^{n} \mathrm{~W}_{\mathrm{j}} X_{i j}^{*}
$$

Keterangan:

$\mathrm{g} \quad=$ Jumlah atribut yang dimaksimalkan

(n-g) = Jumlah atribut yang diminimalkan

$Y_{1} \quad=$ nilai yang telah dinomalisasikan

$W j \quad=$ bobot dari setiap atribut

5. Perangkingan nilai $Y i$

Nilai $Y i$ bisa positif atau negatif tergantung dari total maksimal dan minimal dalam matriks keputusan. Perangkingan nilai $Y i$ dapat dijadikan sebagai hasil keputusan, dimana nilai tertinggi atau terendah dapat dijadikan hasil keputusan.

Metode WASPAS merupakan kerangka kerja untuk membuat keputusan yang efektif pada masalah yang kompleks dengan menyederhanakan dan mempercepat proses pengambilan keputusan dengan menyelesaikan masalah menjadi bagian-bagian dan mengatur bagian-bagian tersebut dalam pengaturan hirarki dan memberian nilai numerik pada subyektif [12]. Metode WASPAS saat ini sangat populer digunakan oleh para peneliti dalam bidang ilmu pengambilan keputusan karena memberikan nilai yang akurat.

Ide dasar dari metode WASPAS adalah mengintegrasikan 2 pendekatan atau model, yaitu model jumlah tertimbang (Weight Sum) dan model produk tertimbang (Weight Product) [13]. Weight Sum dan Weight Product sering dierapkan untuk mengevaluasi sejumlah alternatif dalam beberapa kriteria keputusan [14]. Metode WASPAS merupakan metode yang dapat mengurangi kesalahankesalahan atau mengoptimalkan dalam penaksiran untuk pemilihan nilai tertinggi dan terendah [15]. Maka, metode tersebut diharapkan dapat menyelesaikan masalah dalam membuat keputusan.

Dalam prosesnya, metode WASPAS terdiri dari beberapa langkah sebagai berikut [5]:

1. Menentukan maktriks atribut keputusan, dimana $x i j$ adalah rating performa.

$$
\begin{array}{rcc}
X 11 & X 12 & X 1 n \\
X i j=X 21 & X 22 & X 2 n \\
X m 1 & X m 2 & X m n
\end{array}
$$

2. Menentukan normalisasi nilai $R i j$

Apabila atribut digolongkan kedalam kriteria Benefit, maka rumusnya adalah: 


$$
R i j=\frac{X_{i j}}{\operatorname{Max}_{x i j}}
$$

Apabila atribut digolongkan kedalam kriteria Cost, maka rumusnya adalah:

$$
R i j=\frac{\operatorname{Min}_{x i j}}{X_{i j}}
$$

3. Menghitung nilai alternatif (Qi)

$$
\mathrm{Qi}=0,5 \sum_{j=0}^{n} R_{i j} W j+0,5 \prod_{i=1}^{n}\left(R_{i j}\right) W j
$$

Maka alternatif yang memiliki nilai Qi tertinggi akan menjadi alternatif terbaik.

Metode MOORA dan WASPAS akan dilakukan pembandingan untuk mengetahui hasil keputusan yang terbaik. Metode MOORA terfokus pada pengoptimalan nilai setiap kriteria dari alternatif, sehingga diperoleh hasil keputusan. Sedangkan pada metode WASPAS terfokus pada nilai pembobotan setiap kriteria sehingga diperoleh hasil keputusan. Maka dengan fokus yang berbeda akan dilihat hasil keputusan terbaik dari kedua metode tersebut. Sehingga tujuan dilakukan pembandingan kedua metode ini adalah untuk mengetahui hasil keputusan terbaik dari kedua metode dalam fokus yang berbeda.

Penelitian dengan menggunakan metode WASPAS pernah dilakukan dalam sistem pendukung pemilihan games untuk remaja. Pada penelitian tersebut, ditentukan 4 jenis kriteria penilaian dan 7 data alternatif. Selanjutnya dilakukan proses matriks keputusan dan ternomalisasi sehingga menghasilkan keputusan. Dari penelitian tersebut dihasilkan sebuah keputusan dengan nilai tertinggi sebagai keputusannya, dimana diperoleh nilai sebesar 2,7907 sebagai nilai tertinggi [5].

Penggunaan metode MOORA juga dilakukan dalam penelitian penyeleksian siswa calon peserta olimpiade. Pada penelitian tersebut dilakukan pengolahan data kriteria sebanyan 7 jenis kriteria dan 6 data alternatif. Selanjutnya dilakukan proses matriks keutusan dan normalisasi matriks sampai dengan perangkingan. Sehingga dari proses tersebut dihasilkan keputusan berupa nilai tertinggi sebagai hasil keputusan, dimana nilai 0,4139 sebagai nilai tertinggi [6].

Dari penelitian dengan menggunakan metode MOORA dan WASPAS tersebut, maka dapat dibandingkan metode mana yang dapat menghasikan keputusan terbaik dalam menentukan mata pelajaran yang menjadi prioritas utama dalam peningkatan kualitas.

\section{METODE}

Pada penelitian ini, dapat dijelaskan langkah-langkah dalam proses pengambilan keputusan untuk menentukan prioritas dalam perbaikan mata pelajaran dengan menggunakan metode-metode yang digunakan seperti pada Gambar 3.

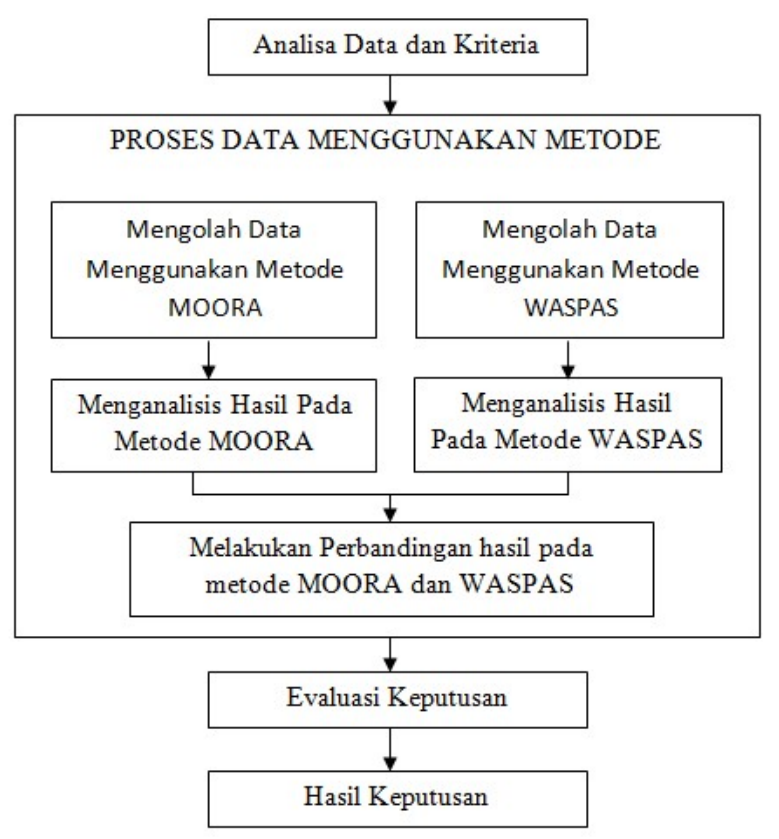

Gambar 3. Tahapan Proses Penelitian

Dari Gambar 2 tersebut, maka dapat dijelaskan tahapan dari penelitian tersebut sebagai berikut:

\subsection{Analisis Data}

Data yang digunakan dalam penelitian ini, diperoleh melalui bagian tata usaha SMAN 2 Kota Cirebon pada siswa jurusan IPA kelas 12 Data yang diperoleh, adalah berupa data kriteria penilaian serta data-data mata pelajaran yang ada pada SMAN 2 Kota Cirebon. Adapun data kriteria yang digunakan dalam penentuan prioritas utama mata pelajaran yang akan ditingkatkan kualitasnya adalah

\begin{tabular}{|c|c|c|c|c|c|}
\hline Kode & $\begin{array}{l}\text { Nama } \\
\text { Kriteria } \\
\end{array}$ & Sub Kriteria & $\begin{array}{l}\text { Bobot } \\
\text { Sub }\end{array}$ & Type & $\begin{array}{l}\text { Bobot } \\
\text { Kriteria } \\
\end{array}$ \\
\hline K1 & $\begin{array}{l}\text { Rata-rata } \\
\text { Nilai } \\
\text { Kompetensi }\end{array}$ & $\begin{array}{l}>=90 \\
75-89 \\
66-74 \\
<=65\end{array}$ & $\begin{array}{l}1 \\
0,75 \\
0,5 \\
0,25\end{array}$ & Benefit & 3,5 \\
\hline K2 & $\begin{array}{l}\text { Jumlah } \\
\text { Siswa } \\
\text { Dibawah } \\
\text { KKM }\end{array}$ & $\begin{array}{l}>10 \text { Siswa } \\
5-9 \text { Siswa } \\
1-4 \text { Siswa } \\
0 \text { Siswa }\end{array}$ & $\begin{array}{l}1 \\
0,75 \\
0,5 \\
0,25\end{array}$ & Cost & 3 \\
\hline K3 & Keaktifan & $\begin{array}{l}\text { Aktif } \\
\text { Kurang aktif }\end{array}$ & $\begin{array}{l}0,75 \\
0,25\end{array}$ & Benefit & 2 \\
\hline K4 & $\begin{array}{l}\text { Kemampuan } \\
\text { Merangkum }\end{array}$ & $\begin{array}{l}\text { Mampu } \\
\text { Kurang Mampu }\end{array}$ & $\begin{array}{l}0,75 \\
0,25\end{array}$ & Benefit & 1,5 \\
\hline
\end{tabular}
seperti pada Tabel 1 berikut:

Tabel 1. Data Kriteria Penilaian

Selanjutnya, untuk data alternatif dilakukan pengujian sebanyak 6 mata pelajaran, adapun mata pelajaran yang digunakan dilihat pada Tabel 2 berikut:

Tabel 2. Data Alternatif 


\begin{tabular}{ll}
\hline Kode Alternatif & Nama Mata Pelajaran \\
\hline A1 & Matematika \\
A2 & Biologi \\
A3 & Kimia \\
A4 & Fisika \\
A5 & Bahasa Inggris \\
A6 & Bahasa Indonesia \\
\hline
\end{tabular}

Dari data yang telah diproses, maka dapat dilakukan proses metode yang digunakan.

\subsection{Proses Data Menggunakan Metode}

Data kriteria dan data alternatif yang telah dianalisa, selanjutnya dilakukan proses perhitungan metode WASPAS dan MOORA. kedua metode tersebut memiliki langkah yang berbeda, dengan begitu hasil dari proses kedua metode tersebut juga memiliki hasil yang berbeda. Hasil kedua metode tersebut akan dilakukan evaluasi keputusan untuk bisa mendapatkan hasil keputusan yang baik. Dari kedua hasil metode tersebut akan dilihat hasil terbaik yang dapat dijadikan keputusan.

\subsection{Perbandingan Hasil Metode WASPAS dan MOORA}

Setelah diperoleh hasil dari proses kedua metode, selanjutnya akan dilakukan perbandingan hasil dari kedua metode. Dari hasil kedua metode tersebut akan dilihat hasil keputusan mana yang lebih relevan dan cocok untuk dijadikan sebagai sebuah keputusan. Hasil metode yang dipilih sebagai keputusan selanjuttnya akan dilakukan evaluasi keputusan.

\subsection{Evaluasi Keputusan}

Setelah diperoleh hasil keputusan dari kedua metode, selanjutnya dilakukan evaluasi terhadap hasil keputusan. Pada evaluasi keputusan ini, hasil kedua metode akan dibandingkan dan dievaluasi hasil metode mana yang cocok untuk menjadi keputusan. Metode dengan hasil keputusan yang cocok akan dipilih sebagai hasil keputusan akhir dari proses sistem pendukung keputusan untuk menentukan prioritas utama mata pelajaran yang perlu ditingkatkan kualitasnya .

\subsection{Hasil}

Hasil keputusan merupakan tujuan akhir dari proses sistem pendukung keputusan ini. Hasil dari keputusan ini akan menjadi alat bantu atau referensi bagi pihak sekolah dalam menentukan mata pelajaran yang menjadi prioritas utama dalam peningkatan kualitasnya.

\section{HASIL DAN PEMBAHASAN}

Dari metodologi penelitian yang telah dibahas sebelumnya, maka dapat dijelaskan proses penentuan mata pelajaran yang menjadi prioritas utama dalam peningkatan kualitas menggunakan metode WASPAS dan MOORA. Adapun langkah-langah untuk proses tersebut dapat dilihat sebagai berikut.

\subsection{Proses Metode MOORA}

Untuk proses metode MOORA, dilakukan pengujian terhadap data uji atau data sampel seperti pada Tabel 3 berikut:

Tabel 3. Data Uji / Sampel

\begin{tabular}{|c|c|c|c|c|}
\hline \multirow{2}{*}{ Alternatif } & \multicolumn{4}{|c|}{ Kriteria } \\
\hline & K1 & K2 & K3 & K4 \\
\hline A1 & 85 & 6 Siswa & Aktif & Mampu \\
\hline \multirow{2}{*}{ A2 } & \multirow{2}{*}{80} & 3 Siswa & Aktif & Kurang \\
\hline & & & & Mampu \\
\hline \multirow{2}{*}{ A3 } & \multirow{2}{*}{72} & 8 Siswa & Kurang & Kurang \\
\hline & & & Aktif & Mampu \\
\hline \multirow{2}{*}{ A4 } & \multirow{2}{*}{79} & 6 Siswa & Kurang & Mampu \\
\hline & & & Aktif & \\
\hline \multirow{2}{*}{ A5 } & \multirow{2}{*}{70} & 3 Siswa & Kurang & Mampu \\
\hline & & & Aktif & \\
\hline \multirow{2}{*}{ A6 } & \multirow{2}{*}{85} & 0 Siswa & Kurang & Mampu \\
\hline & & & Aktif & \\
\hline
\end{tabular}

Dari data diatas, maka dilakukan penyesuaian pada sub kriteria kedalam bentuk bobot sub kriteria atau disebut dengan matrik keputusan seperti pada Tabel 4 berikut:

Tabel 4. Matrik Keputusan Metode MOORA

\begin{tabular}{lllll}
\hline \multirow{2}{*}{ Alternatif } & \multicolumn{4}{c}{ Kriteria } \\
\cline { 2 - 5 } & K1 & K2 & K3 & K4 \\
\hline A1 & 0,75 & 0,75 & 0,75 & 0,75 \\
A2 & 0,75 & 0,5 & 0,75 & 0,25 \\
A3 & 0,5 & 0,75 & 0,25 & 0,25 \\
A4 & 0,75 & 0,75 & 0,25 & 0,75 \\
A5 & 0,5 & 0,5 & 0,25 & 0,75 \\
A6 & 0,75 & 0,25 & 0,25 & 0,75 \\
\hline
\end{tabular}

Tahapan selanjutnya adalah melakukan proses normalisasi pada matrik keputusan. Maka dengan menggunakan rumus, diperoleh nilai normalisasi sebagai berikut:

\section{Alternatif A1 :}

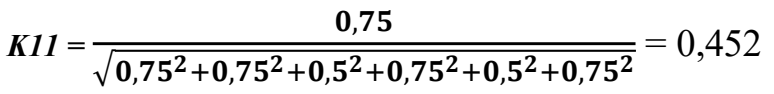

$$
\begin{aligned}
& K 12=\frac{0,75}{\sqrt{0,75^{2}+0,5^{2}+0,75^{2}+0,75^{2}+0,5^{2}+0,25^{2}}}=0,5
\end{aligned}
$$

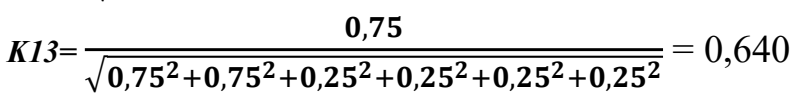

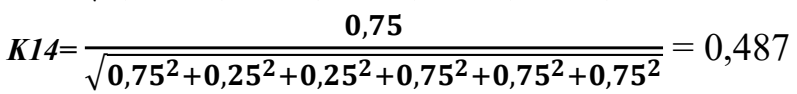

Alternatif A2 :

$$
\begin{aligned}
& K 21=\frac{\mathbf{0 , 7 5}}{\sqrt{\mathbf{0 , 7 5}^{2}+0,75^{2}+0,5^{2}+0,75^{2}+0,5^{2}+0,75^{2}}}=0,452
\end{aligned}
$$

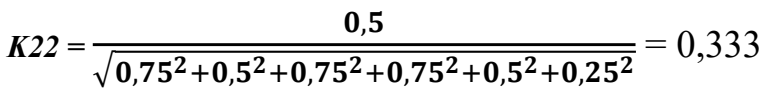

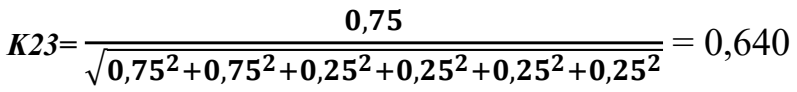




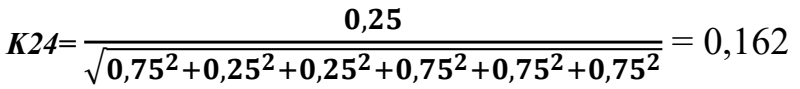

Alternatif A3 :

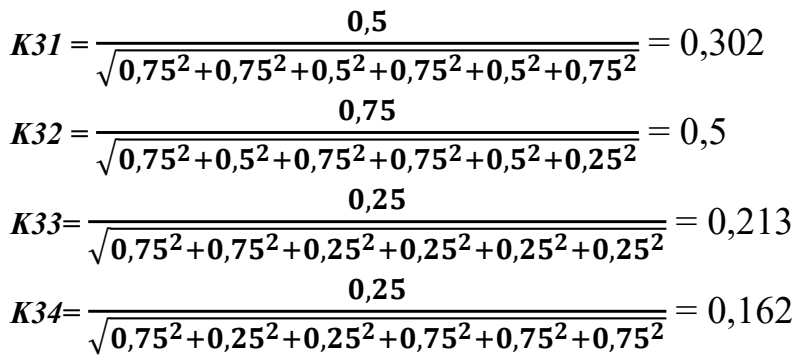

Alternatif A4 :

$K 41=\frac{0,75}{\sqrt{0,75^{2}+0,75^{2}+0,5^{2}+0,75^{2}+0,5^{2}+0,75^{2}}}=0,452$

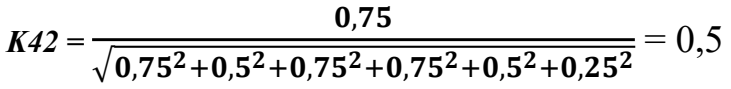

$K 43=\frac{0,25}{\sqrt{0,75^{2}+0,75^{2}+0,25^{2}+0,25^{2}+0,25^{2}+0,25^{2}}}=0,213$

$K 44=\frac{\mathbf{0 , 7 5}}{\sqrt{\mathbf{0 , 7 5}^{2}+0,25^{2}+0,25^{2}+0,75^{2}+0,75^{2}+0,75^{2}}}=0,487$

Alternatif A5 :

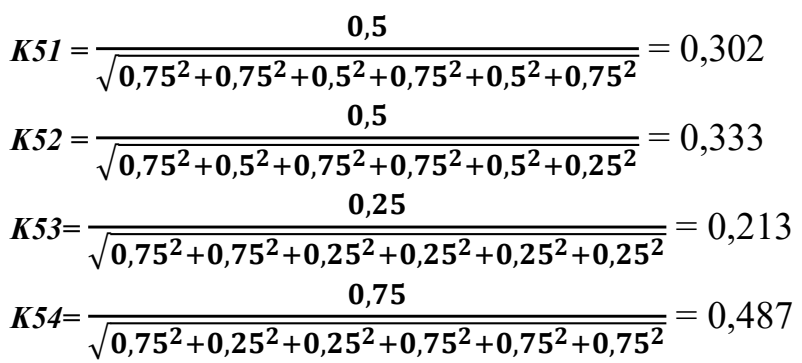

Alternatif A6 :

$K 11=\frac{0,75}{\sqrt{0,75^{2}+0,75^{2}+0,5^{2}+0,75^{2}+0,5^{2}+0,75^{\mathbf{2}}}}=0,452$

$K 12=\frac{0,25}{\sqrt{0,75^{2}+0,5^{2}+0,75^{2}+0,75^{2}+0,5^{2}+0,25^{2}}}=0,167$

$K 13=\frac{0,25}{\sqrt{\mathbf{0 , 7 5}^{2}+0,75^{2}+0,25^{2}+0,25^{2}+0,25^{2}+0,25^{2}}}=0,213$

$K 14=\frac{\mathbf{0 , 7 5}}{\sqrt{\mathbf{0 , 7 5}^{2}+\mathbf{0 , 2 5}^{2}+\mathbf{0 , 2 5}^{2}+\mathbf{0 , 7 5}^{2}+\mathbf{0 , 7 5}^{2}+\mathbf{0 , 7 5 ^ { 2 }}}}=0,487$

Tabel 5. Normalisasi

\begin{tabular}{lllll}
\hline \multirow{2}{*}{ Alternatif } & \multicolumn{4}{c}{ Kriteria } \\
\cline { 2 - 5 } & K1 & K2 & K3 & K4 \\
\hline A1 & 0,452 & 0,5 & 0,640 & 0,487 \\
A2 & 0,452 & 0,333 & 0,640 & 0,162 \\
A3 & 0,302 & 0,5 & 0,213 & 0,162 \\
A4 & 0,452 & 0,5 & 0,213 & 0,487 \\
A5 & 0,302 & 0,333 & 0,213 & 0,487 \\
A6 & 0,452 & 0,167 & 0,213 & 0,487 \\
\hline
\end{tabular}

Selanjutnya untuk hasil normalisasi keseluruhannya dapat dilihat pada Tabel 5. Setelah diperoleh hasil normalisasi, selanjutnya dilakukan proses optimalisasi. Dalam proses optimalisasi, nilai bobot per kirteria dikalikan pada masing-masing nilai normalisasi seperti berikut:

Untuk kriteria type benefit terdapat 3 kriteria didalamnya, maka untuk nilai optimalisasi diperoleh sebagai berikut:

a. Untuk Kriteria 1

$K^{*} 11=0,452 \times 3,5=1,583$

$K^{*} 12=0,452 \times 3,5=1,583$

$K^{*} 13=0,302 \times 3,5=1,055$

$K^{*} 14=0,452 \times 3,5=1,583$

$K^{*} 15=0,302 \times 3,5=1,055$

$K^{*} 16=0,452 \times 3,5=1,583$

b. Untuk Kriteria 3

$K^{*} 31=0,640 \times 2=1,279$

$K^{*} 32=0,640 \times 2=1,279$

$K^{*} 33=0,213 \times 2=0,426$

$K^{*} 34=0,213 \times 2=0,426$

$K^{*} 35=0,213 \times 2=0,426$

$K^{*} 36=0,213 \times 2=0,426$

c. Untuk Kriteria 4

$K^{*} 41=0,487 \times 1,5=0,730$

$K^{*} 42=0,162 \times 1,5=0,243$

$K^{*} 43=0,162 \times 1,5=0,243$

$K^{*} 44=0,487 \times 1,5=0,730$

$K^{*} 45=0,487 \times 1,5=0,730$

$K^{*} 46=0,487 \times 1,5=0,730$

Sedangkan untuk type cost terdapat 1 kriteria didalamnya, maka nilai optimalisasi diperoleh sebagai berikut:

a. Untuk Kriteria 2

$$
\begin{aligned}
& K^{*} 21=-1(0,500 \times 3)=-1,5 \\
& K^{*} 22=-1(0,333 \times 3)=-1 \\
& K^{*} 23=-1(0,500 \times 3)=-1,5 \\
& K^{*} 24=-1(0,500 \times 3)=-1,5 \\
& K^{*} 25=-1(0,333 \times 3)=-1 \\
& K^{*} 26=-1(0,167 \times 3)=-0,5
\end{aligned}
$$

Proses selanjutnya adalah menentukan nilai optimalisasi total untuk setiap alternatif. Maka proses untuk menentukan nilai optimalisasi total adalah sebaagai berikut:

$$
\begin{aligned}
& Y 1=(1,583+1,279+0,730)-1,5=2,09 \\
& Y 2=(1,583+1,279+0,243)-1=2,11 \\
& Y 3=(1,055+0,426+0,243)-1,5=0,23
\end{aligned}
$$




$$
\begin{aligned}
& Y 4=(1,583+0,426+0,730)-1,5=1,24 \\
& Y 5=(1,055+0,426+0,730)-1,5=1,21 \\
& Y 6=(1,583+0,426+0,730)-0,5=2,24
\end{aligned}
$$

Dari hasil yang diperoleh, maka dilakukan perangkingan hasil, adapun hasil perangkingan dapat dilihat pada Tabel 6 .

Tabel 6. Perangkingan Hasil Metode MOORA

\begin{tabular}{lll}
\hline Ranking & Mata Pelajaran & Nilai Optimalisasi \\
\hline 1 & Bahasa Indonesia & 2,24 \\
2 & Biologi & 2,11 \\
3 & Matematika & 2,09 \\
4 & Fisika & 1,24 \\
5 & Bahasa Inggris & 1,21 \\
6 & Kimia & 0,23 \\
\hline
\end{tabular}

Dari hasil metode MOORA, ditemukan 3 mata pelajaran yang perlu diperbaiki kualitasnya, yaitu Fisika, Bahasa Inggris dan Kimia disebabkan 3 mata pelajaran tersebut nilainya berada dibawah 50\% jika dibandingkan dari nilai mata pelajaran terbaik. Dari perolehan hasil nilai optimalisasi diatas, maka mata pelajaran Kimia menjadi prioritas utama dalam peningkatan kualitas mata pelajaran.

\subsection{Proses Metode WASPAS}

Untuk proses metode WASPAS juga dilakukan pengujian terhadap data uji seperti yang ada pada Tabel 3. Selanjutnya dari data uji tersebut, ditentukan bobot sub kriteria untuk setiap data atau maktriks keputusan. Matriks keputusan tersebut dapat dilihat pada Tabel 7.

Tabel 7. Matrik Keputusan Metode WASPAS

\begin{tabular}{lllll}
\hline \multirow{2}{*}{ Alternatif } & \multicolumn{4}{c}{ Kriteria } \\
\cline { 2 - 5 } & K1 & K2 & K3 & K4 \\
\hline A1 & 0,75 & 0,75 & 0,75 & 0,75 \\
A2 & 0,75 & 0,5 & 0,75 & 0,25 \\
A3 & 0,5 & 0,75 & 0,25 & 0,25 \\
A4 & 0,75 & 0,75 & 0,25 & 0,75 \\
A5 & 0,5 & 0,5 & 0,25 & 0,75 \\
A6 & 0,75 & 0,25 & 0,25 & 0,75 \\
\hline
\end{tabular}

Selanjutnya, dari matriks keputusan, ditentukan nilai tertinggi dan terendah untuk setiap kriteria. Adapun nilai maksimal dan minimal setiap kriteria dapat dilihat pada Tabel 8.

Tabel 8. Nilai Maksimal dan Minimal Matrik Keputusan

\begin{tabular}{lllll}
\hline & \multicolumn{4}{c}{ Kriteria } \\
\cline { 2 - 5 } & K1 & K2 & K3 & K4 \\
\hline MAX & 0,75 & 0,75 & 0,75 & 0,75 \\
MIN & 0,5 & 0,25 & 0,25 & 0,25
\end{tabular}

Langkah selanjutnya adalah melakukan normalisasi untuk setiap nilai matrik keputusan. Untuk melakukan normalisasi nilai, maka dapat melakukan proses sebagai berikut:
Untuk kriteria dengan type benefit terdapat 3 kriteria didalamnya, maka nilai normalisasi diperoleh sebagai berikut:

Untuk Kriteria 1 Nilai MAX $=\mathbf{0 , 7 5}$

$$
\begin{aligned}
& R 11=\frac{0,75}{0,75}=1 \\
& R 12=\frac{0,75}{0,75}=1 \\
& R 13=\frac{0,5}{0,75}=0,667 \\
& R 14=\frac{0,75}{0,75}=1 \\
& R 15=\frac{0,5}{0,75}=0,667 \\
& R 16=\frac{0,75}{0,75}=1
\end{aligned}
$$

Untuk Kriteria 3 Nilai MAX $=0,75$

$$
\begin{aligned}
& R 31=\frac{0,75}{0,75}=1 \\
& R 32=\frac{0,75}{0,75}=1 \\
& R 33=\frac{0,25}{0,75}=0,333 \\
& R 34=\frac{0,25}{0,75}=0,333 \\
& R 53=\frac{0,25}{0,75}=0,333 \\
& R 36=\frac{0,25}{0,75}=0,333
\end{aligned}
$$

Untuk Kriteria 4 Nilai MAX $=0,75$

$$
\begin{aligned}
& R 41=\frac{0,75}{0,75}=1 \\
& R 42=\frac{0,25}{0,75}=0,333 \\
& R 43=\frac{0,25}{0,75}=0,333 \\
& R 44=\frac{0,75}{0,75}=1 \\
& R 45=\frac{0,75}{0,75}=1 \\
& R 46=\frac{0,75}{0,75}=1
\end{aligned}
$$

Sedangkan untuk kriteria dengan type cost terdapat 1 kriteria didalamnya, maka nilai normalisasi diperoleh sebagai berikut:

Untuk Kriteria 2 Nilai MIN $=0,25$

$$
\begin{aligned}
& R 21=\frac{0,25}{0,75}=0,333 \\
& R 22=\frac{0,25}{0,5}=0,5 \\
& R 23=\frac{0,25}{0,75}=0,333 \\
& R 24=\frac{0,25}{0,75}=0,333
\end{aligned}
$$




$$
\begin{aligned}
& R 25=\frac{0,25}{0,5}=0,5 \\
& R 26=\frac{0,25}{0,25}=1
\end{aligned}
$$

Setelah mendapatkan nilai normalisasi setiap alternatif, maka selanjutnya ditentukan hasil nilai alternatif (Qi). Adapun proses untuk mencari nilai Qi dapat dilihat pada proses berikut:

$$
\begin{aligned}
\mathrm{Q} 1= & \left(0,5 \sum(1 * 3,5)+(0,333 * 3)+(1 * 2)+(1 * 1,5)\right) \\
& +\left(0,5 \Pi(1)^{3,5} *(0,333)^{3} *(1)^{2} *(1)^{1,5}\right) \\
= & \mathbf{5 , 5 1 8} \\
\mathrm{Q} 2= & \left(0,5 \sum(1 * 3,5)+(0,5 * 3)+(1 * 2)+(0,333 * 1,5)\right) \\
& +\left(0,5 \prod(1)^{3,5} *(0,5)^{3} *(1)^{2} *(0,333)^{1,5}\right) \\
= & \mathbf{4 , 9 0 8} \\
\mathrm{Q} 3= & \left(0,5 \sum(0,666 * 3,5)+(0,333 * 3)+(0,333 * 2)+\right. \\
& (0,333 * 1,5))+ \\
& \left(0,5 \Pi(0,666)^{3,5} *(0,333)^{3} *(0,333)^{2} *(0,333)^{1,5}\right) \\
= & \mathbf{2 , 5 4 1} \\
\mathrm{Q} 4= & \left(0,5 \sum(1 * 3,5)+(0,333 * 3)+(0,333 * 2)+(1 * 1,5)\right) \\
& +\left(0,5 \prod(1)^{3,5} *(0,333)^{3} *(0,333)^{2} *(1)^{1,5}\right) \\
= & \mathbf{4 , 4 0 7} \\
\mathrm{Q} 5= & \left(0,5 \sum(0,666 * 3,5)+(0,5 * 3)+(0,333 * 2)+(1 * 1,5)\right) \\
& +\left(0,5 \prod(0,666)^{3,5} *(0,5)^{3} *(0,333)^{2} *(1)^{1,5}\right) \\
= & \mathbf{3 , 7 3 9} \\
\mathrm{Q} 6= & \left(0,5 \sum(1 * 3,5)+(1 * 3)+(0,333 * 2)+(1 * 1,5)\right) \\
& +\left(0,5 \prod(1)^{3,5} *(1)^{3} *(0,333)^{2} *(1)^{1,5}\right) \\
= & \mathbf{5 , 8 8 8}
\end{aligned}
$$

Dari hasil proses pencarian nilai Qi, maka dapat dilakukan perangkingan pada hasil tersebut seperti pada Tabel 9.

Tabel 9. Perangkingan Hasil Metode WASPAS

\begin{tabular}{lll}
\hline Ranking & Mata Pelajaran & Nilai Optimalisasi \\
\hline 1 & Bahasa Indonesia & 5,888 \\
2 & Matematika & 5,518 \\
3 & Biologi & 4,908 \\
4 & Fisika & 4,407 \\
5 & Bahasa Inggris & 3,739 \\
6 & Kimia & 2,541 \\
\hline
\end{tabular}

Dari hasil metode WASPAS ditemukan 1 mata pelajaran yang perlu diperbaiki kualitasnya, yaitu mata pelajaran Kimia. disebabkan mata pelajaran Kimia tersebut nilainya berada dibawah $50 \%$ jika dibandingkan dari nilai mata pelajaran terbaik. Maka ditentukan mata pelajaran tersebut yang perlu ditingkatkan kualitasnya dengan mata pelajaran Kimia sebagai prioritas utama dalam peningkatan kualitas mata pelajaran.

\subsection{Hasil Keputusan}

Setelah melakukan proses analisa data dengan menggunakan metode MOORA dan WASPAS, maka dapat diambil keputusan terbaik dalam penentuan mata pelajaran yang menjadi prioritas utama dalam peningkatan kualitas. Pada metode MOORA ditemukan 3 mata pelajaran yang perlu dilakukan perbaiki karena nilainya berada $50 \%$ dibawah nilai tertingggi, sedangkan pada metode WASPAS terdapat 1 mata pelajaran yang perlu dilakukan perbaikan karena nilainya berada $50 \%$ dibawah nilai tertinggi. Namun dari hasil akhir metode MOORA dan WASPAS memiliki kesamaan, yaitu mata pelajaran Kimia memiliki nilai optimalisasi terendah, sehinggan mata pelajaran Kimia menjadi prioritas utama dalam peningkatan kualitas.

\section{KESIMPULAN}

Metode MOORA dan WASPAS telah dapat melakukan analisa terhadap data-data yang telah diperoleh dalam penentuan mata pelajaran yang menjadi prioritas utama dalam peningkatan kualitas. Dari hasil kedua metode, didapatkan hasil keputusan mata pelajaran Kimia sebagai mata pelajaran yang menjadi prioritas utama dalam peningkatan kualitasnya.

Dalam perbandingan kedua metode, pada metode MOORA ditemukan 3 mata pelajaran yang perlu ada perbaikan, sedangkan pada metode WASPAS hanya terdapat 1 mata pelajaran yang perlu ada perbaikan. Maka metode WASPAS dapat dijadikan metode pilihan dalam menganalisa proses keputusan dikarena metode WASPAS memberikan hasil yang akurat dan jelas dibandingkan dengan metode MOORA.

Selanjutnya dapat disimpulkan keunggulan dari desain ini adalah kedua metode dapat memproses multi-kriteria dalam pengambilan keputusan, serta pembandingan kedua metode, dapat memberikan keputusan yang beragam bagi seorang pengambil keputusan. Selain dari itu, untuk keterbatasan desain sendiri, kedua metode dipengaruhi oleh nilai bobot kriterianya dan juga kurangnya kriteria-kriteria penilaian dalam proses pengambilan keputusan ini.

\section{DAFTAR PUSTAKA}

[1] A. Pane and M. D. Dasopang, "Belajar Dan Pembelajaran" FITRAH Jurnal Kajian Ilmu-Ilmu Keislaman, vol. 03, pp. 333-352, 2017, ISSN 2442-6997.

[2] H. Hasan, "Kendala Yang Dihadapi Guru Dalam Proses Belajar Mengajar Matematika Di SD Negeri Gani Kabupaten Aceh Besar" Jurnal Pesona Dasar, vol. 01, pp. 40-51, 2015, ISSN 2337-9227.

[3] M. Ilham, I. Parlina, A. Maulana, E. K. Lubis and S. I. Sari, "Sistem Pendukung Keputusan Pemilihan SMA Negeri Terfavorit Kota Pematangsiantar Menggunakan Metode 
MOORA"Jurnal Nasional Informatika dan Teknologi Jaringan, vol. 03, pp. 16-20, 2019, ISSN 2540-7597.

[4] C. Nas, S. Defit and J. Santoni, "Evaluasi Mutasi Jabatan Anggota Kepolisian Menggunakan Metode Profile Matching dan Multi Attribute Utility Theory" Jurnal Sains, Teknologi dan Industri, vol. 16, pp. 30-36, 2018, ISSN 1693-2390.

[5] A. Safitra, I. A. Lubis and N. Siregar, "Sistem Pendukung Keputusan Pemilihan Games Untuk Remaja Menggunakan Metode WASPAS," in Seminar Nasional Sains \& Teknologi Informasi, SENSASI 2018, Medan, Sumatera Utara, Indonesia, July 28, 2018, pp. 141-147.

[6] S. Wardani, Solikhun and A. Revi, "Analisis Sistem Pendukung Keputusan Penyeleksian Siswa Calon Peserta Olimpiade Dengan Metode MOORA" Jurnal Teknovasi, vol. 5, pp. 18-26, 2018, ISSN 2540-8389.

[7] G. S. Mahendra and K. Y. E. Aryanto, "SPK Penentuan Lokasi ATM Menggunakan AHP dan SAW" Jurnal Nasional Teknologi dan Sistem Informasi, vol. 5, pp. 49-56, 2019, ISSN 2460-3465

[8] Y. Wahyudi, Suwarni and Andayani, "Sistem Pendukung Keputusan Pengangkatan Pegawai Negeri Sipil Dalam Jabatan Struktural Pada Badan Kepegawaian Daerah Provinsi Bengkulu" Jurnal Media Infotama, vol. 9, pp. 190-210, 2013, ISSN 1858-2680.

[9] R. Romiyadi,"Sistem Penunjang Kepetusan Penentuan Topik Tugas Akhir Mahasiswa Program Studi Manajemen Informatika ," Jurnal Bianglala Informatika, vol. 04, pp. 1-10, 2016, ISSN 1979-9330.

[10] V. S. Gadakh, " Application of MOORA Methode For Parametric Optimization Of Milling Process " International Jurnal Of Applied Engineering Research, vol. 01, pp. 743-758, 2011, ISSN 0976-4259.

[11] M.Yazdani, S. Fomba and P. Zarate, "A Decision Support System For Multiple Criteria Decission Making Problems," in 17th International Conference on Group Decision and Negotiation, Stuttgart,Germany, August 14 - August 18, 2017.

[12] D. Stanujkic and D. Karabasevic, " An Extension Of The Waspas Method For Decision-Making Problems With Intuitionistic Fuzzy Numbers: A Case Of Website Evaluation " Operational Research in Engineering Sciences: Theory And Applications, vol. 02, pp. 29-39, 2018, ISSN 2620-1607.

[13] M.Handayani and N. Marpaung, "Implementasi Metode Weight Aggregated Sum Product Assesment (WASPAS) Dalam Pemilihan Kepala Laboratorium," in Seminar Nasional Royal, SENAR 2018, Asahan,Sumatera Utara, Indonesia, September 3, 2018, pp. 253-258, ISSN 2622-9986.

[14] R. S. Dwitama, "Pemilihan Metode Multi Criteria Decision Making (MCDM) Menggunakan Pendekatan Rank Similarity Simulation (RSS)," in Seminar Nasional Hasil Penelitian Dan Pengabdian 2019, Bandar Lampung, Lampung, Indonesia, Agustus 28, 2019, pp. 27-37.

[15] Tundo and D. Kurniawan, "Implementation Of The Weighted Aggregated Sum Product Assesment Method In Determining The Best Rice For Serabi Cake Making” International Journal On Informatics For Development, vol 8, pp. 40-46, 2019, ISSN 2549-7448.
[16] R. Suhartono, "Upaya Peningkatan Kualitas Pembelajaran Membubut Mata Pelajaran Kerja Mesin Lanjut Menggunakan Model Praktik Berpasangan" Jurnal Pendidikan Vokasi, vol. 4, pp. 57-66, 2014, ISSN 2476-9401.

[17] S. Dadi, "Peningkatan Kualitas Pembelajaran IPS Melalui Pemanfaatan Model Kelas Di Kelas V Sekolah Dasar Negeri 38 Kota Bengkulu" Jurnal Ilmiah Pendidikan Guru Sekolah Dasar, vol. 9, pp. 255-260, 2016, ISSN 1693-8577. 